\title{
Genetic and epigenetic modifications induced by chemotherapeutic drugs: human amniotic fluid stem cells as an in- vitro model
}

\author{
Prabin Upadhyaya ${ }^{1}$, Alessandra Di Serafino ${ }^{1}$, Luca Sorino ${ }^{1}$, Patrizia Ballerini ${ }^{1,2}$, Marco Marchisio ${ }^{1,2}$, \\ Laura Pierdomenico ${ }^{1,2}$, Liborio Stuppia ${ }^{1,2}$ and Ivana Antonucci ${ }^{1,2^{*}}$
}

\begin{abstract}
Background: Bleomycin, etoposide and cisplatin (BEP) are three chemotherapeutic agents widely used individually or in combination with each other or other chemotherapeutic agents in the treatment of various cancers. These chemotherapeutic agents are cytotoxic; hence, along with killing cancerous cells, they also damage stem cell pools in the body, which causes various negative effects on patients. The epigenetic changes due to the individual action of BEP on stem cells are largely unknown.

Methods: Human amniotic fluid stem cells (hAFSCs) were treated with our in-vitro standardized dosages of BEP individually, for seven days. The cells were harvested after the treatment and extraction of DNA and RNA were performed. Real-time PCR and flow cytometry were conducted for cell markers analysis. The global DNA methylation was quantified using $5 \mathrm{mC}$ specific kit and promoter and CpG methylation \% through bisulfite conversion and pyrosequencing. Micro- RNAs (miRNAs) were quantified with real-time qPCR.

Results: The cytotoxic nature of BEP was observed even at low dosages throughout the experiment. We also investigated the change in the expression of various pluripotent and germline markers and found a significant change in the properties of the cells after the treatments. The methylation of DNA at global, promoter and individual CpG levels largely get fluctuated due to the BEP treatment. Several tested miRNAs showed differential expression. No positive correlation between mRNA and protein expression was observed for some markers.

Conclusion: Cytotoxic chemotherapeutic agents such as BEP were found to alter stem cell properties of hAFSCs. Different methylation profiles change dynamically, which may explain such changes in cellular properties. Data also suggests that the fate of hAFSCs after treatment may depend upon the interplay between the miRNAs. Finally, our results demonstrate that hAFSCs might prove to be a suitable in-vitro model of stem cells to predict genetic and epigenetic modification due to the action of various drugs.
\end{abstract}

Keywords: Human amniotic fluid stem cells, Epigenetics, Bleomycin, Etoposide, Cisplatin, BEP, microRNA, DNA methylation

\footnotetext{
*Correspondence: i.antonucci@unich.it

${ }^{1}$ Department of Psychological, Health and Territorial Sciences, School of

Medicine and Health Sciences, "G.d'Annunzio" University, Chieti-Pescara, Via

dei Vestini 31, 66013 Chieti, Italy

${ }^{2}$ Centre of Aging Science and Translational Medicine (Ce.S.I.-Me.T.), G.

d'Annunzio University, Chieti-Pescara, Italy
}

(c) The Author(s). 2019 Open Access This article is distributed under the terms of the Creative Commons Attribution 4.0 International License (http://creativecommons.org/licenses/by/4.0/), which permits unrestricted use, distribution, and reproduction in any medium, provided you give appropriate credit to the original author(s) and the source, provide a link to the Creative Commons license, and indicate if changes were made. The Creative Commons Public Domain Dedication waiver (http://creativecommons.org/publicdomain/zero/1.0/) applies to the data made available in this article, unless otherwise stated. 


\section{Background}

Cancer is a leading cause of death worldwide [1]. Chemotherapy constitutes the main treatment protocol for almost all tumours. Bleomycin, etoposide and cisplatinum/cisplatin (BEP) are three chemotherapeutic agents that are widely used in solo or in combination with each other (BEP regimen) or with other chemotherapeutic agents [2-4] for the treatment of various cancers [5-9], specially testicular (seminoma and non-seminoma) $[10,11]$ and various subtypes of ovarian cancer [12]. Each anti-cancer drug has a specific mechanism of action to arrest carcinogenesis and in particular, the exposure to these treatments causes cell death or prevent cell growth through inhibiting protein function or DNA synthesis [13-17]. There are some shreds of evidence in the literature that numerous anti-cancer drugs change the epigenetic makeup of the cells [18-21]. Studies have also examined the role of BEP on the sperm epigenome, implying the potential risk to the subsequent generations [22, 23]. The anti-proliferative effects of the different chemotherapeutic agents are key aspects contributing to tumour regression, but unfortunately, it can also affect healthy proliferative tissues, thus defining the limits of the treatment with these drugs. Tissue regeneration after cancer therapy is a crucial point for the preservation of human health, which mainly depends upon the survival of stem cells to replace the dead cells and tissues [24, 25]. The role of stem cells in the replacement of senescent or deteriorated cells of the human body is defined by their capacity of self-renewal and multilineage differentiation. Hence, stem cells can be considered a unique in vitro model to test toxicity and treatment protocols for chemotherapeutic drugs. Human amniotic fluid stem cells (hAFSCs) have been proposed so far to be an interesting model to test specific drugs and to evaluate their efficiency on cell-types of different lineages [26-30]. The hAFSCs are defined as a peculiar class of stem cells, cultivated from secondtrimester amniotic fluid with the properties in between multipotent and pluripotent stem cells and they express a range of markers typical to pluripotent stem cells [31] and primordial germ cells (PGCs) [27]. Despite intensive investigations, still, there is not sound understanding on epigenetic alterations induced by chemotherapy affecting the chromatin architecture or DNA methylation. In light of these premises, the aim of the present study was to investigate epigenetic changes induced by cisplatin, bleomycin and etoposide in hAFSCs. For this purpose, we investigated global DNA methylation, gene-specific DNA methylation including the imprinted gene H19 and microRNAs to elucidate a potential epigenetic mechanism by which chemotherapeutic drugs might alter stemness (by changing the expression of pluripotency and germline markers), cell proliferation, apoptosis and chemosensitivity.

\section{Materials and methods}

Isolation and culture of hAFSCs

Human amniotic fluid samples $(2-3 \mathrm{ml})$ were obtained from women undergoing amniocentesis $(n=8)$ for prenatal diagnosis at 16-18 weeks of pregnancy after written informed consent. All pregnant women received detailed information about the experimental protocol, which was approved by the Ethics Committee of the University of Chieti- Pescara, Italy. hAFSC were isolated from amniotic fluid and cultured until the 5th passage as described by Antonucci et al. [28]. The cells were then seeded into T25 flasks (Thermo Scientific, MA, USA), or in $10 \mathrm{~cm}$ tissue culture grade plates and incubated at $37{ }^{\circ} \mathrm{C}$ in a humidified atmosphere (95\%) under $5 \% \mathrm{CO} 2$.

\section{MTT assay}

Cell viability and dose vs response were assessed using CellTiter $96^{\circ}$ AQueous One Solution Cell Proliferation Assay (Promega Italia s.r.l., Italy), following the Manufacturer's Protocol. Ninety-six well plates were seeded with approximately 3000 cells/well. Counting of the cells were performed using microwell cell counter. After $24 \mathrm{~h}$ of incubation at $37^{\circ} \mathrm{C}$ in a humidified, $5 \% \mathrm{CO}_{2}$ incubator, the hAFSCs get attached at the bottom of the plates. Then the cells were treated with concentration gradients $(0.5 \mu \mathrm{M}, 1 \mu \mathrm{M}, 5 \mu \mathrm{M}, 10 \mu \mathrm{M}, 50 \mu \mathrm{M}, 100 \mu \mathrm{M}, 500 \mu \mathrm{M} \&$ $1000 \mu \mathrm{M})$ of cisplatin, bleomycin and etoposide separately and incubated at the same incubator 24, 48 and 72 $\mathrm{h}$ respectively, in different plates. Preparation of drugs and their concentration gradient is reported on Additional file 1: SI1. After each time interval, $20 \mu \mathrm{l}$ of CellTiter $96^{\circ}$ AQueous One Solution Reagent was added into each well. The plate was incubated at $37^{\circ} \mathrm{C}$ in a humidified atmosphere (95\%) under 5\% CO2 for $2 \mathrm{~h}$ and absorbance was recorded at $490 \mathrm{~nm}$ using readwell $\mathrm{TOUCH}^{\mathrm{T}}$ - Automatic ELISA Plate Analyser (Robonik ${ }^{\oplus}$, India). Background absorbance was first subtracted to each data point using a set of wells containing Iscove's Modified Dulbecco's Medium (IMDM) only, and then a dose-response curve was generated for each drug, in order to evaluate viability with respect to time concentration of those drugs. From the graph, one suitable concentration has been determined for all the future treatments.

\section{Treatment of hAFSCs with BEP regimen}

Once the hAFSCs in the flasks or plates almost 70-80\% confluency $(\sim 700,000$ cells/plate $)$, they were treated separately with Bleomycin (Sigma-Aldrich by Merck, Germany), Etoposide synthetic ( $\geq 98 \%$, powder; Sigma-Aldrich by Merck, Germany) and Cisplatin (European Pharmacopoeia Reference Standard; Sigma-Aldrich by Merck, Germany) for 7 days with $\mathrm{IC}_{5}$ values of the respective drugs. The treatment was performed in between 4th to 6th passage. We decided to treat the cells with least $\left(\mathrm{IC}_{5}\right)$ concentration 
for longer period of the time (7 days) so that the drugs do not violently kill the cells and we retain the sufficient number of cells with the drug-induced stable genetic and epigenetic changes. The preparation of the solutions for all the three drugs is described in supplementary data. The cells were incubated with the drugs for the 7 days in the incubator using the same conditions as mentioned above. The cells were observed visually with the help of an inverted binocular microscope. The old medium was removed and fresh medium in the control and medium with respective concentrations of the drugs has been added in every 2 days. Treated samples do not proliferate much and do not reach $100 \%$ confluency; however, the cells in the control (without treatment) were split once they reached $100 \%$ confluency.

\section{Harvesting the cells}

The cells were harvested after 7 days using the standard trypsinisation protocol. 1X trypsin (Carlo Erba Reagents, Italy) and $1 \mathrm{X}$ Dulbecco's phosphate-buffered saline (PBS) was used for trypsinisation and washing the cells, respectively. After harvesting, the cells with each treatment and control were divided into three equal parts. The cells in the first two parts were used for extraction of DNA and RNA, respectively whereas the whole live cells in third part were used for flow cytometry and protein analysis.

\section{Extraction of DNA and RNA}

Total DNA was extracted with MagPurix Forensic DNA Extraction Kit (MagPurix ${ }^{\ominus}$, Zinexts Life Science, Taiwan) and the automatic DNA extractor (MagPurix ${ }^{\oplus}$, Zinexts Life Science, Taiwan) according to the manufacturer's protocol. The quantification of extracted DNA and was performed using the Qubit DNA assay kit (Life Technologies, ThermoFisher Scientific, MA, USA).

Total RNA was extracted using Ribospin II (GeneAll Biotechnology Co., Seoul, Korea) by following the manufacturer's protocol. RNA quantification was done using the Qubit RNA assay kit (Life Technologies, ThermoFisher Scientific, MA, USA). Colourimetric readings for quantification of DNA and RNA were taken at Qubit 3.0 fluorometer (ThermoFisher Scientific, MA, USA).

\section{Global DNA methylation}

Global DNA methylation quantification was performed on the nuclear DNA (100 ng) extracted using MethylFlash Methylated DNA Quantification kit (Epigentek Group Inc., NY, USA). It is important to specify that the levels of $5-\mathrm{mC}$ generally account for $0.5-2 \%$ in vertebrates as reported in the manufacturer's protocol.

\section{Reverse transcription and real-time PCR}

Reverse transcription was performed to prepare cDNA from the mRNA present in the total RNA using
RevertAid First Strand cDNA Synthesis Kit (Thermo Scientific by ThermoFisher Scientific, MA, USA) using the manufacturer's protocol. $100 \mathrm{ng}$ of input total RNA was incubated at $65{ }^{\circ} \mathrm{C}$ for 5 min with $1 \mu \mathrm{L}$ of $100 \mu \mathrm{M}$ oligo (dT)18 primer and nuclease-free water with a total volume of $12 \mu \mathrm{L}$. Then, $1 \mu \mathrm{L}$ of RNase inhibitor, $4 \mu \mathrm{L}$ of reaction buffer, $1 \mu \mathrm{L}$ of reverse transcriptase and $2 \mu \mathrm{L}$ of dNTP mix is added to the above mix and incubated at $45^{\circ} \mathrm{C}$ for $1 \mathrm{~h}$ and $70{ }^{\circ} \mathrm{C}$ for $5 \mathrm{~min}$. Thus, $20 \mu \mathrm{L}$ of cDNA was prepared for each sample. For realtime-qPCR, highly purified salt-free primers for all the target and reference (GAPDH) genes were ordered from Eurofins genomics, Germany (Table 1). The real-time qPCR was performed using SYBR Green chemistry. The samples were analysed in technical duplicates and the total volume for each reaction was $20 \mu \mathrm{L}$, which comprised of $10 \mu \mathrm{L}$ of $2 \mathrm{X}$ master-mix, $0.6 \mu \mathrm{L}$ of $100 \mathrm{pmol} / \mu \mathrm{L}$ forward primer, $0.6 \mu \mathrm{L}$ of $100 \mathrm{pmol} / \mu \mathrm{L}$ reverse primer, $2 \mu \mathrm{L}$ of $\mathrm{cDNA}(\sim$ $10 \mathrm{ng} / \mu \mathrm{L})$ and $6.8 \mu \mathrm{L}$ of nuclease-free PCR grade water. The 96 well $0.2 \mu \mathrm{L}$ reactions plates containing different genes were run on real-time PCR instrument (Quant Studio 5, Applied Biosystems, ThermoFisher Scientific, MA, USA) with the standard protocol (Table 2).

\section{miRNA analysis}

Eight miRNAs associated with pluripotency and differentiation along with one endogenous control, all purchased as Single-tube TaqMan Advanced miRNA assays (Applied Biosystems, ThermoFisher Scientific, MA, USA) were selected for the study (Table 3). cDNA was synthesized from total RNA using TaqMan Advanced miRNA cDNA Synthesis Kit (Applied biosystem, ThermoFisher Scientific, MA, USA) by following manufacturer's protocol (Applied Biosystems, ThermoFisher Scientific, MA, USA). The kit produces cDNAs from mature miRNAs in the total RNA samples by extending the $3^{\prime}$ end of the mature transcript through poly (A) addition and then lengthening the $5^{\prime}$ end by adaptor ligation. The modified miRNAs then undergo universal reverse transcription followed by amplification to increase uniformly the amount of cDNA from all miRNAs. The prepared cDNA was diluted 1:10 in 1X TE buffer. After the preparation of cDNA, real-time PCR reaction plates were prepared using the manufacturer's protocol (Applied Biosystems, ThermoFisher Scientific, MA, USA). The $20 \mu \mathrm{l}$ of each PCR reaction included $10 \mu \mathrm{L}$ of TaqMan Fast Advanced Master Mix (2x) (Applied Biosystems, ThermoFisher Scientific, MA, USA), $1 \mu \mathrm{L}$ of TaqMan Advanced miRNA Assay (20X) (Biosystems, ThermoFisher Scientific, MA, USA), $4 \mu \mathrm{L}$ of RNase free water and $5 \mu \mathrm{L}$ of diluted cDNA $(2.5-5 \mathrm{ng})$. The reactions were run on quant studio 5 in a 96-well optical plate at $95^{\circ} \mathrm{C}$ for $20 \mathrm{~s}$, 1 cycle (enzyme activation), followed by 40 cycles of $95^{\circ} \mathrm{C}$ for $1 \mathrm{~s}$ (denaturation) and $60{ }^{\circ} \mathrm{C}$ for $20 \mathrm{~s}$ 
Table 1 Primers for realtime PCR

\begin{tabular}{|c|c|c|c|c|c|}
\hline \multirow[t]{2}{*}{ \# } & \multirow[t]{2}{*}{ Gene } & \multicolumn{2}{|l|}{ Forward Primer $\left(5^{\prime}->3^{\prime}\right)$} & \multicolumn{2}{|l|}{ Reverse Primer $\left(5^{\prime}->3^{\prime}\right)$} \\
\hline & & Sequence & -mer & Sequence & -mer \\
\hline 1 & $c-K i t$ & CCACACCCTGTTCACTCCTT & 20 & TTCTGGGAAACTCCCAT TTG & 20 \\
\hline 2 & Oct-4 & CTTGCTGCAGAAGTGGGTGGAGGAA & 25 & CTGCAGTGTGGGTTTCGGGCA & 21 \\
\hline 3 & Sox-2 & TTGCTGCCTCTTTAAGACTAGGA & 23 & CTGGGGCTCAAACTTCTCTC & 20 \\
\hline 4 & $c-M y c$ & TCAAGAGGCGAACACACAAC & 20 & GGCCTITCATTGTTTTCCA & 20 \\
\hline 5 & $K \mid f-4$ & AAGCCAAAGAGGGGAAGACG & 20 & CATGTGTAAGGCGAGGTGGT & 20 \\
\hline 6 & Vasa & CTTAGACCCAGACGAATGTATGC & 23 & GTTCACTTCCACTGCCACTTC & 21 \\
\hline 7 & Boll & GCAAGAAGAGCCTTGTTAATG & 21 & CCTCAGAAGGTTGCAGGTATAAG & 23 \\
\hline 8 & Stella & GCGGAGTTCGTACGCATGA & 19 & CCATCCATTAGACACGCAGAAA & 22 \\
\hline 9 & Dazl & GCTCGCCTGACGCCATCTTTG & 21 & GCTGATGAGGACTGGGTGCTG & 21 \\
\hline 10 & Piwil-2 & TGGTTGGAGTAGGACGCTTG & 20 & GGGACGGTGTGCTGAAGG & 18 \\
\hline 11 & Fragilis & GCACCCTCTACCTGAATCTG & 20 & AGGATGTTGTAGCACTTGGC & 20 \\
\hline 12 & Sycp-3 & TGCAGGAGTAGTTGAAGATATG & 22 & CTAGCATGTCCTTAAGAAGCCTGTC & 25 \\
\hline 13 & Stra-8 & AAGGACAGCGGCGTGG AC & 18 & CTGGCAAGCACTGAACTGGAG & 21 \\
\hline 14 & GAPDH (Reference gene) & ACCATCTTCCAGGAGCGAGA & 20 & AGTGATGGCATGGACTGTGG & 20 \\
\hline
\end{tabular}

(annealing/extension). The $\mathrm{Ct}$ data were determined using default threshold settings. The threshold cycle $(\mathrm{Ct})$ is defined as the fractional cycle number at which the fluorescence passes the fixed threshold. Relative quantification was calculated in terms of delta delta $\mathrm{Ct}(\Delta \Delta \mathrm{Ct})$.

\section{Bisulfite conversion and pyrosequencing}

PCR and sequencing primers were designed using the PyroMark $^{\odot}$ assay design software version 2.0 (QIAGEN, Germany) (Table 4). Extracted DNA from all the samples were modified using BisulFlashTM DNA Modification Kit (Epigentek Group Inc., NY, USA) which is capable of modifying $200 \mathrm{pg}$ to $1 \mu \mathrm{g}$ of DNA. The kit claims to convert $99.9 \%$ of unmethylated cytosine into uracil with less than $10 \%$ loss of DNA during conversion steps. We used $100 \mathrm{ng}$ of input DNA for each sample for Bisulfite conversion. The bisulfite-treated samples were then amplified by PCR (SimpliAmp, Applied Biosystems, ThermoFisher Scientific, MA, USA), using forward and reverse primers (Table 4 for PCR primers and

Table 2 Protocol for Realtime GPCR with SYBR-green chemistry

\begin{tabular}{llll}
\hline STEP & TEMPERATURE & TIME & NO. OF CYCLES \\
\hline UDG pre-treatment & $50^{\circ} \mathrm{C}$ & $2 \mathrm{~min}$ & 1 \\
Initial denaturation & $95^{\circ} \mathrm{C}$ & $10 \mathrm{~min}$ & 1 \\
Denaturation & $95^{\circ} \mathrm{C}$ & $15 \mathrm{~s}$ & 40 cycles \\
$\begin{array}{l}\text { Annealing and Extension } \\
\text { (data acquisition) }\end{array}$ & $60^{\circ} \mathrm{C}$ (example) & $30 \mathrm{~s}$ & \\
Denaturation for melt curve & $95^{\circ} \mathrm{C}$ & $15 \mathrm{~s}$ & 1 \\
Annealing and extension & 60 & $1 \mathrm{~min}$ & \\
(data acquisition) & 95 & $15 \mathrm{~s}$ & \\
Dissociation for melt curve & & & \\
\hline
\end{tabular}

conditions), in which one of the primers is biotinylated. We have used KAPA HiFi HotStart Uracil+ Ready Mix PCR kit (Kapa Biosystems, Roche, Switzerland) for amplification of bisulfite-converted DNA with $1 \mu \mathrm{L}$ of converted DNA, $0.5 \mu \mathrm{L}$ of forward and $0.5 \mu \mathrm{L}$ of reverse primer, $12.5 \mu \mathrm{L}$ of Kapa Master mix, and $10.5 \mu \mathrm{L}$ of PCR grade water for each sample. The amplification cycles include initial denaturation at $95^{\circ} \mathrm{C}$ for $3 \mathrm{~min}, 30$ cycles of denaturation $\left(98^{\circ} \mathrm{C}\right.$ for $20 \mathrm{~s}$ ), annealing (always $15 \mathrm{~s}$; for annealing temperatures of different genes, Table 1) and extension $\left(72^{\circ} \mathrm{C}\right.$ for $1 \mathrm{~min}$ ) followed by 1 cycle of final extension $\left(72{ }^{\circ} \mathrm{C}\right.$ for $\left.1 \mathrm{~min}\right)$. We did electrophoresis (Major Science, CA, USA) using $1.5 \mu \mathrm{L}$ of the post-PCR products to visualise our band of interest and to eliminate the samples showing trailing or non-specific bands. We then used Sepharose beads (sequencing beads) to purify the final PCR product using a biotin-labelled primer. The PCR product was bound to Streptavidin Sepharose HP (Diatech pharmacogenetics, Italy), and the Sepharose beads containing the immobilized PCR products were captured using the PyroMark ${ }^{\circledR}$ Q96 vacuum preparation tool (QIAGEN, Germany), and then washed with $50 \mathrm{~mL}$ of $70 \%$ ethanol for $5 \mathrm{~s}$, denatured with $40 \mathrm{~mL}$ of denaturation solution (Diatech pharmacogenetics, Italy) for $5 \mathrm{~s}$, and neutralized with $50 \mathrm{~mL}$ of wash buffer (Diatech pharmacogenetics, Italy) for $10 \mathrm{~s}$. The biotinylated single-stranded PCR products were then released into a 96-well format plate (Pyro ID plate, Diatech pharmacogenetics, Italy) containing $2 \mu \mathrm{L}$ of 100 pmol pyrosequencing primer suspended in $38 \mu \mathrm{L}$ of annealing buffer. Annealing of the sequencing primer to the single-stranded DNA was performed by incubating the plates on a prewarmed heat block (QBD2 Grant, Wolf 
Table 3 Selected miRNAs used in the study

\begin{tabular}{|c|c|c|c|}
\hline miRBase ID: & Assay ID (thermo scientific) & Stem-loop Accession \# & Mature miRNA Sequence \\
\hline hsa-miR-372-5p & 478854_mir & MI0000780 & CCUCAAAUGUGGAGCACUAUUCU \\
\hline hsa-mir-34a & 478047_mir & MI0000268 & CAAUCAGCAAGUAUACUGCCCU \\
\hline hsa-miR-17-3p & 477932_mir & MI0000071 & ACUGCAGUGAAGGCACUUGUAG \\
\hline hsa-let-7a-5p & 478575_mir & MI0000060 & UGAGGUAGUAGGUUGUAUAGUU \\
\hline hsa-miR-449a & 478561_mir & MI0001648 & UGGCAGUGUAUUGUUAGCUGGU \\
\hline hsa-miR-34c-5p & 478052_mir & MI0000743 & AGGCAGUGUAGUUAGCUGAUUGC \\
\hline hsa-miR-122-3p & 477874_mir & MI0000442 & AACGCCAUUAUCACACUAAAUA \\
\hline hsa-miR-185-5p & 477939_mir & MI0000482 & UGGAGAGAAAGGCAGUUCCUGA \\
\hline hsa-miR-106b-5p & 478412_mir & MI0000734 & UAAAGUGCUGACAGUGCAGAU \\
\hline hsa-miR-145-3p & 477915_mir & MI0000461 & GGAUUCCUGGAAAUACUGUUCU \\
\hline hsa-miR-361-5p (endogenous control) & 478056_mir & MI0000760 & UUAUCAGAAUCUCCAGGGGUAC \\
\hline
\end{tabular}

Laboratories, UK) at $80{ }^{\circ} \mathrm{C}$ for $2 \mathrm{~min}$ followed by incubation at room temperature for $10 \mathrm{~min}$. After annealing, the plate was loaded into the PyroMark ${ }^{\circ}$ Q96 instrument (QIAGEN, Germany). Appropriate amounts of enzyme, substrate, and dNTPs (all purchased from Diatech pharmacogenetics, Italy) biotin-labelled in the appropriate wells of the cartridge (Pyro ID cartridge, Diatech Pharmacogenetics, Italy) and the cartridge is carefully inserted into the instrument prior to sequencing. The software PyroMark ${ }^{\circ} \mathrm{CpG}$ (QIAGEN, Germany) was prepared in the meantime. Predetermined variable positions of the CpG sites were chosen for respective markers using the assay software. The software automatically generates a dispensation order of dNTPs and control dispensations based on the sequence to analyze. Control dispensations (not part of the sequence to analyze) were included in the dispensation order to check the performance of the reactions. Usually, there was one control injection at the beginning of the sequence and then approximately one for every $\mathrm{CpG}$ site. There was no chemiluminescence expected at these control injections and they were used to monitor the reagents and the sequence quality. Then the PyroMark ${ }^{\circ}$ Q96 instrument was run and the analysis was performed. Following the sequencing reaction, the data collected were analyzed using the PyroMark ${ }^{\circ}$ Q96 software for CpG methylation quantitation and the corresponding percent methylation values for each site and the data were displayed as a pyrogram. The percentage of methylation was expressed for each DNA locus as \%5-mC divided by the sum of methylated and unmethylated cytosines. We tested each marker in technical duplicates and used their average in the statistical analyses.

\section{Immunophenotyping with flow cytometry Antibodies used}

Primary unconjugated anti-human monoclonal antibodies (IgG) against OCT4, SOX2 and NANOG proteins, and appropriate secondary fluorophore-conjugated antibodies which bind with those IgG were used for flow cytometry. The primary monoclonal antibodies used were mouse anti-human SOX2 antibody (ThermoFisher Scientific, MA, USA), mouse anti-human NANOG antibody (ThermoFisher Scientific, MA, USA) and rabbit anti-human OCT4 antibody (ThermoFisher Scientific, MA, USA). The secondary antibodies used were Alexa Fluor 488 conjugated goat anti-mouse IgG antibody (ThermoFisher Scientific, MA, USA) and Alexa Fluor ${ }^{\circ} 532$ conjugated goat anti-Rabbit IgG $(\mathrm{H}+\mathrm{L})$ cross-adsorbed antibody (ThermoFisher Scientific, MA, USA).

\section{Flow cytometry analysis}

hAFSCs were stained with anti-human primary antibodies, in order to analyse the expression of protein markers, with some modifications in the procedure described before [32, 33]. Briefly, $5 \times 105$ cells were incubated with $100 \mu \mathrm{l} 20 \mathrm{mM}$ ethylenediaminetetraacetic acid (EDTA) at $37^{\circ} \mathrm{C}$ for $10 \mathrm{~min}$ and then washed. Washing buffer (phosphate-buffered saline [PBS], 0.1\% sodium azide, $0.5 \%$ bovine serum albumin) was used for all of the washing steps $(3 \mathrm{ml}$ washing buffer, with centrifugation at $400 \times \mathrm{g}$ for $8 \mathrm{~min}$ at $4{ }^{\circ} \mathrm{C}$ ). To increase the permeability of the membranes for antibodies in case of intracellular staining, $1 \mathrm{ml}$ Perm 2 (Becton, Dickinson and Company, Franklin Lakes, New Jersey, USA) was added to each tube and the cells were incubated for 10 min at room temperature in the dark. The samples were then washed and resuspended in $100 \mu \mathrm{l}$ washing buffer containing the appropriate amount of primary antibody as per manufacturer's instructions and incubated for 30 min at $4{ }^{\circ} \mathrm{C}$ in the dark. At the end of this incubation, the cells were washed thrice. If secondary antibody staining is required, the samples were re-suspended in 3\% BSA/PBS containing fluorophore-labelled secondary antibody at the optimal dilution as per manufacturer's instructions. The cells were then incubated for $30 \mathrm{~min}$ at 


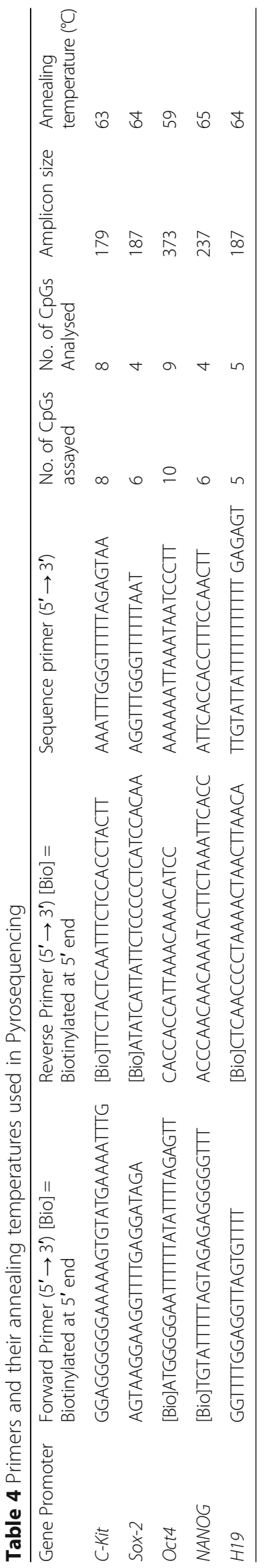


$4{ }^{\circ} \mathrm{C}$ in the dark, washed thrice and fixed in $1 \mathrm{~mL}$ of $0.5 \%$ paraformaldehyde with $5 \mathrm{~min}$ incubation at room temperature. Then the cells were washed by centrifugation and resuspended in washing buffer and kept at $4{ }^{\circ} \mathrm{C}$ in the dark until analysed using a FACSCanto flow cytometer (BD Biosciences by Becton, Dickinson and Company, NJ, USA) and the FACDiva v6.1.3 software (BD Biosciences by Becton, Dickinson and Company, NJ, USA). Quality control was performed using a regular check with Rainbow Calibration Particles (BD Biosciences by Becton, Dickinson and Company, NJ, USA). Debris was excluded from the analysis by gating on the morphological parameters, and 20,000 non-debris events in the morphological gate were recorded for each sample. To assess the nonspecific fluorescence, we used isotype controls. All of the antibodies were titrated under assay conditions and optimal photomultiplier voltages were established for each channel. The data were analysed using the FlowJoTM software (Tree Star Inc., OR, USA). The mean fluorescence intensity (MFI) ratio was calculated by dividing the MFI of positive events by the MFI of negative events.

\section{Statistical analysis}

For individual sample, technical duplicates or triplicates were used depending upon the type of the experiment and their averages were taken for data interpretation. Such averages from 5 to 8 different hAFSC lines were obtained from each experiment and processed statistically, using Microsoft Excel 2010 (Washington, USA) and Graph Pad Prism V6 (California, USA). Doseresponse time curves and respective IC values were determined using nonlinear regression. Statistical significance was determined using analysis of variance (ANOVA) and Student's t-test, depending upon the data type. ANOVA was performed when multiple concentrations of the same drug are compared (as in dose vs viability for different concentrations). Student's t-test was used when two data sets were compared (as in control vs bleomycin/cisplatin/ etoposide) and adjusted using the Holm-Sidak correction. Data are presented as mean \pm SD. $P$ values were expressed as $* * * *$ when $p<0.0001$, *** when $p<0.001$, ** when $p<0.01$ and * when $p<0.05$.

\section{Results}

\section{Cytotoxic effects of BEP on hAFSCs}

Treatment with concentration gradient $(0.1 \mu \mathrm{M}$ to $1000 \mu \mathrm{M})$ followed by 3-(4,5-dimethylthiazol-2-yl)-2,5diphenyl tetrazolium bromide (MTT) assay suggested that hAFSCs display a significant decrease in viability in a dose and time-dependent manner when treated with cisplatin, bleomycin and etoposide (Fig. 1 b). From the dose-response curve, it was found that $\mathrm{IC}_{50}$ values get decreased with longer duration of the treatments (Table 5). However, the curve becomes properly sigmoidal at $48 \mathrm{~h}$, suggesting it as a suitable time for short duration cytotoxicity experiments (Fig. 1 b). To get drug-induced stable genetic and epigenetic changes, we decided to treat the cells for a longer period of time (7 days). Since the cytotoxicity of the drugs increases with time, we treated the cells with a concentration 10 times more dilute $\left(\mathrm{IC}_{5}\right)$ than $\mathrm{IC}_{50}$ of $48 \mathrm{~h}$ so that the drugs do not violently kill the cells and we retain a sufficient number of cells. The hAFSCs were therefore treated for seven days with calculated $\mathrm{IC}_{5}$ concentrations, i.e. $0.5 \mu \mathrm{M}$ for Cisplatin, $2 \mu \mathrm{M}$ for bleomycin and $10 \mu \mathrm{M}$ for etoposide, respectively (Fig. 1 a and Table 5). Under these experimental conditions, the hAFSCs showed less viability with a toxic effect on cell density and cell growth, as documented by microscopic images (Fig. $1 \mathrm{c}$ ).

\section{Effect of BEP regimen on the expression of pluripotency and germ cell markers}

Real-time PCR was performed to study the effect of anticancer drugs on a subset of pluripotency markers, as well as germ cell-specific genes, at 7 days post-treatment. hAFSCs exposed to cisplatin and etoposide presented a downregulation of pluripotency markers (Oct4, SOX2, KLF4, $c-M y c$ and NANOG) $(P<0.05)$ while expression of the Oct4, NANOG and SOX2 were upregulated in cell culture treated with bleomycin $(\mathrm{P}<0.05)$, as shown in Fig. 2 a. Subsequently, markers of premeiotic (Stella, Fragilis, Vasa, STRA8, PIWIL2, DAZL) and meiotic (BOLL, SCYP3) stages of germline cells were studied. Transcriptionally, these three drugs appear to act completely different. Notably, more or less downregulation of all germline markers was detected in cells treated with cisplatin while etoposide had induced a slight reduction in the expression of meiotic stage markers except for STRA8 and PIWIL2. In contrast, bleomycin has induced the upregulation of the expression of most of the premeiotic and all meiotic genes (Fig. 2 b).

\section{Evaluation of pluripotency markers with flow cytometry on hAFSCs after treatment with BEP}

We used flow cytometry to assess the expression profile of the principal pluripotency markers in treated hAFSCs with BEP regimen. In Fig. 3, we have reported the mean fluorescence intensity (MFI) ratio \pm SD for each gene and their respective phenotypes. Contrary to realtime qPCR data, the expression of the transcription factor Oct 4 was found to be increased after the exposure of the cells to cisplatin and etoposide (Fig. 3). Conversely, the expression of SOX2, which is another transcription factor essential for the maintenance of pluripotency in stem cells, was found to be decreased during treatment with cisplatin and bleomycin, whereas it was not significantly decreased during etoposide treatment. Additionally, the expression of NANOG, an antigen associated with the maintenance of pluripotency and self-renewal was not significantly changed during any treatment (Fig. 3). 


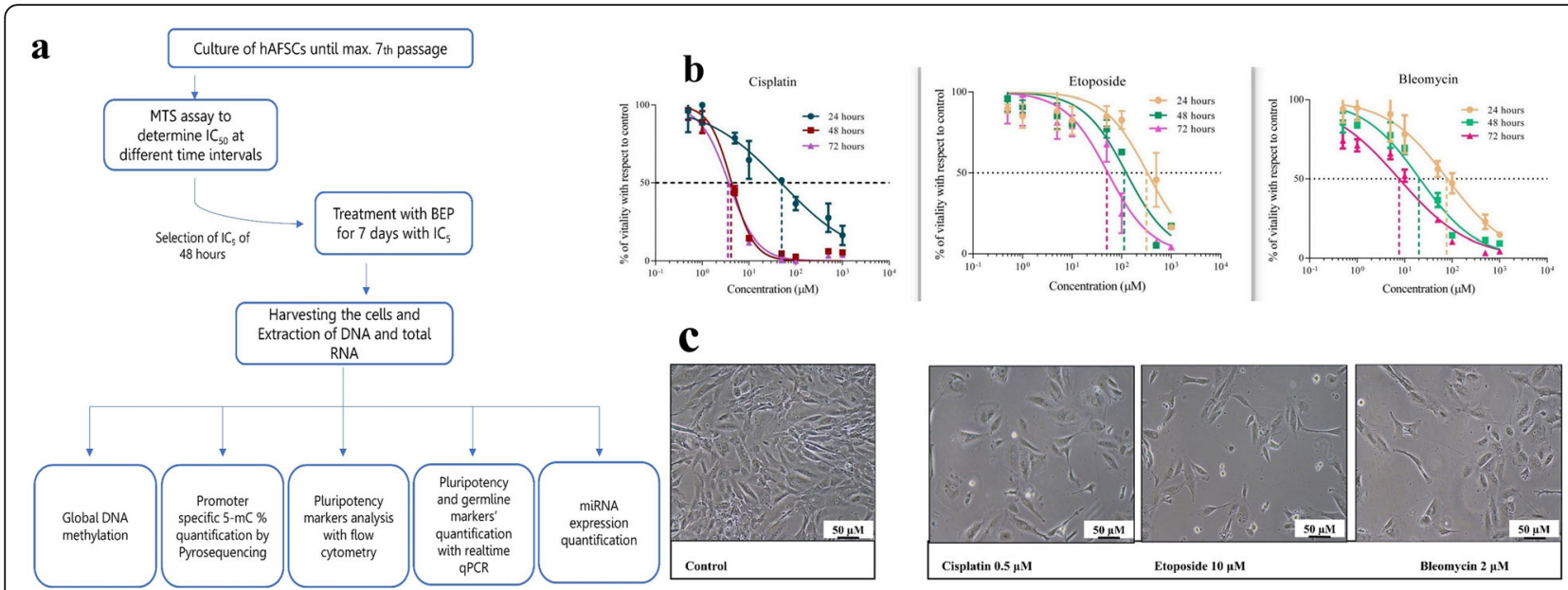

Fig. 1 a Experimental design. b Dose-response curve determining IC50 value after BEP treatment at 24, 48 and $72 \mathrm{~h}$ c Microscopic photographs of the hAFSCs after 7 days of BEP treatment. Photos were taken under 10X magnification. Decrease in cell density in treatment with respect to control due to cytotoxic action of the drugs can be clearly seen

\section{Global and gene-specific DNA methylation profiles of hAFSCs after treatment}

The analysis of global 5'-methylcytosine $(5-\mathrm{mC})$ in the genomic DNA of treated cells showed statistically significant changes. The measured 5-mC levels ranged from 0.8 to $3 \%$ (Fig. 4 a). The averages of five biological replicates have been used as controls and for each treatment (Additional file 1: SI2). As compared to control cells, a decrease in global methylation status was observed in hAFSCs treated with cisplatin $(0.8 \%$ vs $1.1 \% ; P<0.01)$. On the contrary, a higher percentage of methylation was found in cultures exposed to bleomycin and etoposide, 1.7 and 3.0\% respectively $(P<0.0001)$ (Fig. 4 a). Concerning the methylation of specific-genes, the modifications of promoter CpG islands tend to be highly dynamic and significantly variable for each specific treatment. The methylation profiles of the candidate promoter regions were determined by pyrosequencing analysis and revealed that $S O X 2$, C-Kit and NANOG were hypermethylated in hAFSCs treated with cisplatin $(47.7,29,31 \%$, respectively) compared to control (18.6, 19.6, 23.3\%, respectively), with the sole exception of decreased methylation of Oct4 after treatment (33.7\% vs $46 \%$ ) (Fig. 4 b). In addition, the methylation status of cells treated with etoposide exhibited a hypomethylation of SOX2, Oct4 and cKit (12.7, 25.3 and 12\%, respectively) except for hypermethylated NANOG (35.6\%). Under bleomycin treatment, the promoter region of Oct4 and C-Kit genes were significantly hypomethylated (26 and $17.6 \%$ respectively) while high levels of methylation were present in SOX2 and NANOG (49.6 and 47.6\%) (Fig. $4 \mathrm{~b})$. The majority of the CpG sites were hypomethylated in all analyzed treatments. On the other hand, the methylation status of $\mathrm{CpG}$ islands in $\mathrm{H} 19$ was investigated and dynamic changes of this paternally imprinted gene were observed in all treatments., H19 hypomethylation was found in cells cultured with cisplatin with respect to control $(54.3 \%$ vs $63.6 \%, P<0.01)$ while hypermethylation was exhibited by hAFSCs treated with etoposide and bleomycin ( 89 and $80.6 \%$ respectively, $P<0.0001$ ) as reported in Fig. $4 \mathrm{~b}$ and $4 \mathrm{c}$. It is important to emphasize that the data presented revealed that DNA methylation and gene expression are not always positively correlated (Fig. $4 \mathrm{~b}$ and Fig. 2). Interestingly, it has been observed that analysed CpG site 3 of Oct4 was fully demethylated (30 to 0\%) in all pharmacological exposures (Fig. $4 \mathrm{c}$ ). In addition to this, CpG-6 and 7 were also fully demethylated (0\%) in

Table $5 \mathrm{I} \mathrm{C}_{50}$ and corresponding $I \mathrm{C}_{5}$ values for BEP at 24,48 and $72 \mathrm{~h}$

\begin{tabular}{|c|c|c|c|c|c|c|c|}
\hline & \multicolumn{3}{|c|}{$\mathrm{IC}_{50}[\mu \mathrm{M}]$} & \multirow{2}{*}{$\begin{array}{l}P \text { value }^{\mathrm{a}} \text { (for IC50) corresponding } \\
\text { to } 24,48 \text { and } 72 \mathrm{~h}\end{array}$} & \multicolumn{3}{|c|}{ IC5 [ } \\
\hline & $24 \mathrm{~h}$ & $48 \mathrm{~h}$ & $72 \mathrm{~h}$ & & $24 \mathrm{~h}$ & $48 h^{c}$ & $72 \mathrm{~h}$ \\
\hline Cisplatin & 50 & 5 & 3 & $<0.001$ & 5 & 0.5 & 0.3 \\
\hline Etoposide & 300 & 100 & 40 & $<0.001$ & 30 & 10 & 4 \\
\hline Bleomycin & 80 & 20 & 8 & $<0.001$ & 8 & 2 & 0.8 \\
\hline
\end{tabular}

${ }^{\mathrm{a}}$ Significance was determinated by ANOVA, individually for 24,48 and $72 \mathrm{~h}$

${ }^{\mathrm{b}} \mathrm{C}_{5}$ used were the concentration $10 \mathrm{X}$ dilute than $\mathrm{IC}_{50}$

${ }^{\mathrm{C}}$ For uniformity, we have used $\mathrm{IC}_{5}$ of $48 \mathrm{~h}$ for all the drugs throughout the study 


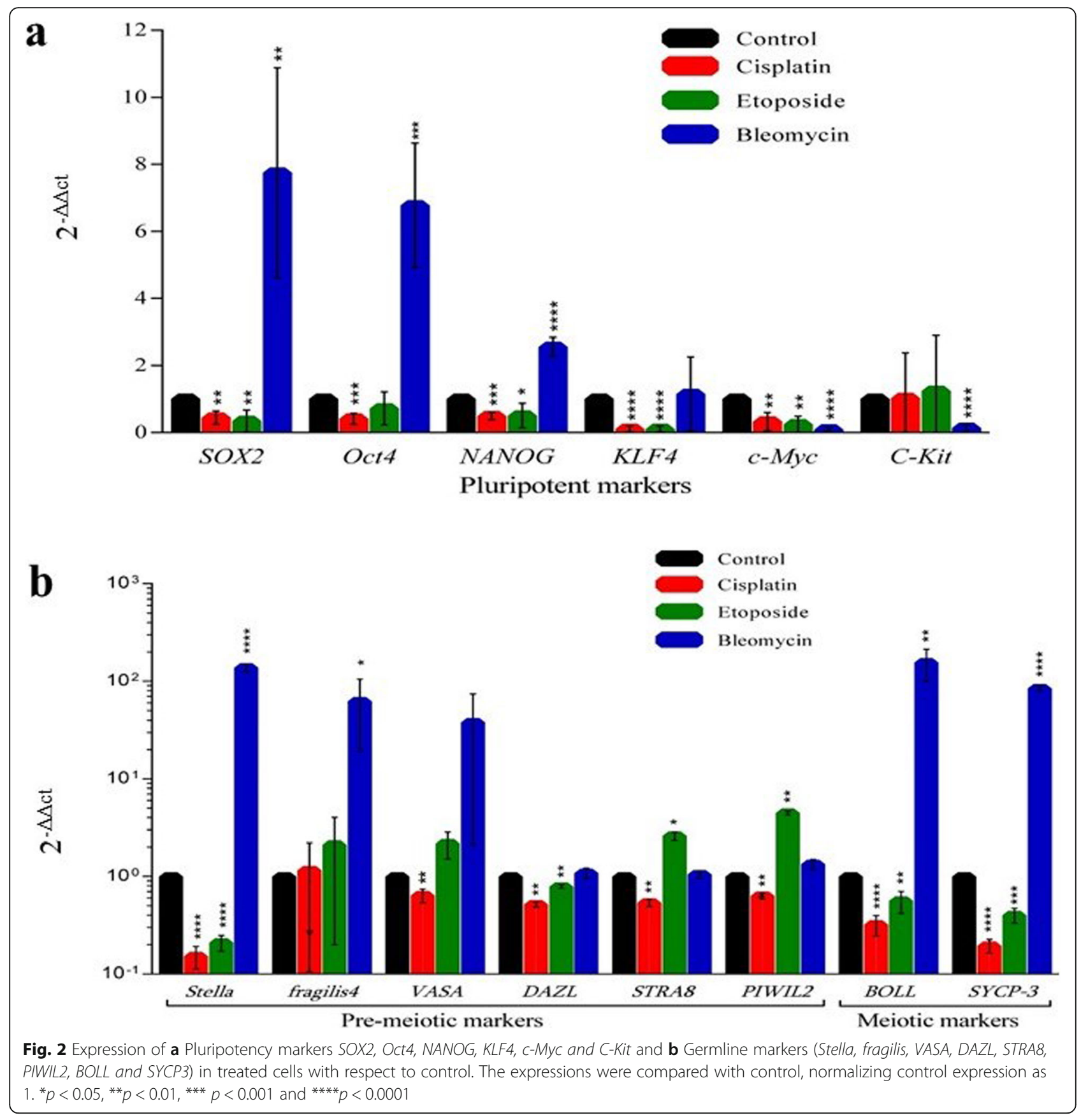

etoposide treatment and CpG-6 in bleomycin treatment. Surprisingly, on the contrary to Oct4, some of the CpG sites of H19 promoters were heavily methylated with a maximum of 100\% methylation. Explicitly, analysed CpG2 and CpG-3 were heavily hypermethylated ( 100\%) during bleomycin and etoposide treatment (Fig. $4 \mathrm{c}$ ).

\section{Dynamic changes in miRNA expression during BEP} treatment

In order to identify miRNA changes associated with anticancer therapy, a panel of 8 small non- coding RNAs was analyzed with the use of realtime-qPCR comparing treated cells with control. The miRNAs with a significant difference in expression $(P<0.5)$ are reported in Fig. 5 and Table 6 . These miRNAs were specifically chosen as a result of detailed literature search as they are involved in a variety of biological processes (Table 6) such as: pluripotency (hsa-miR-145-3p) [34], cell cycle and cell proliferation (hsa-miR-106b-5p, hsa-miR-185-5p, let-7a5p) [35-38], Apoptosis (hsa- miR-34a, hsa- miR-17-3p) $[39,40]$ and chemosensitivity (hsa-miR-34c-5p, hsa-miR449a) [41-44] (Fig. 5). The amount of each miRNA 


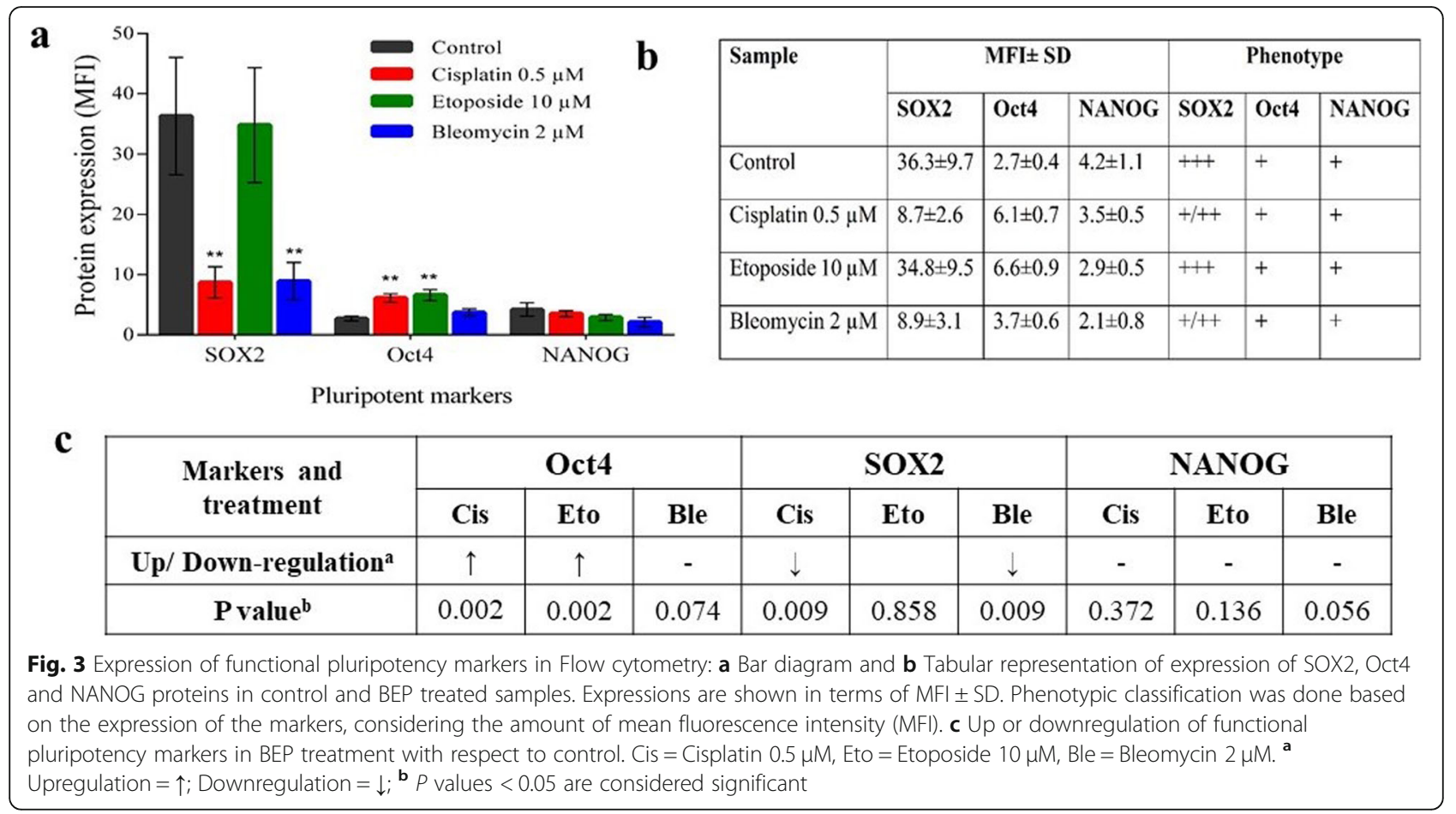

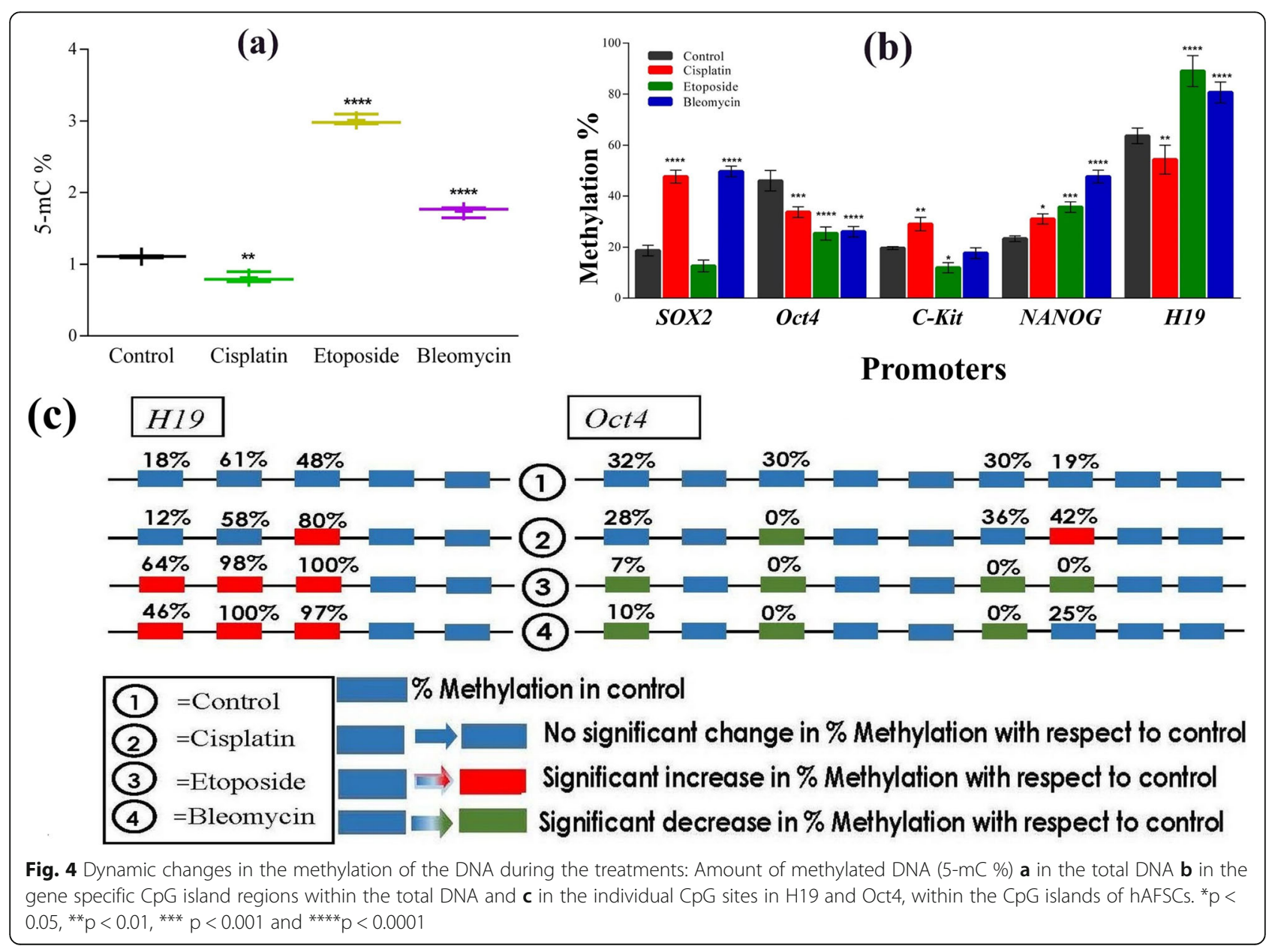




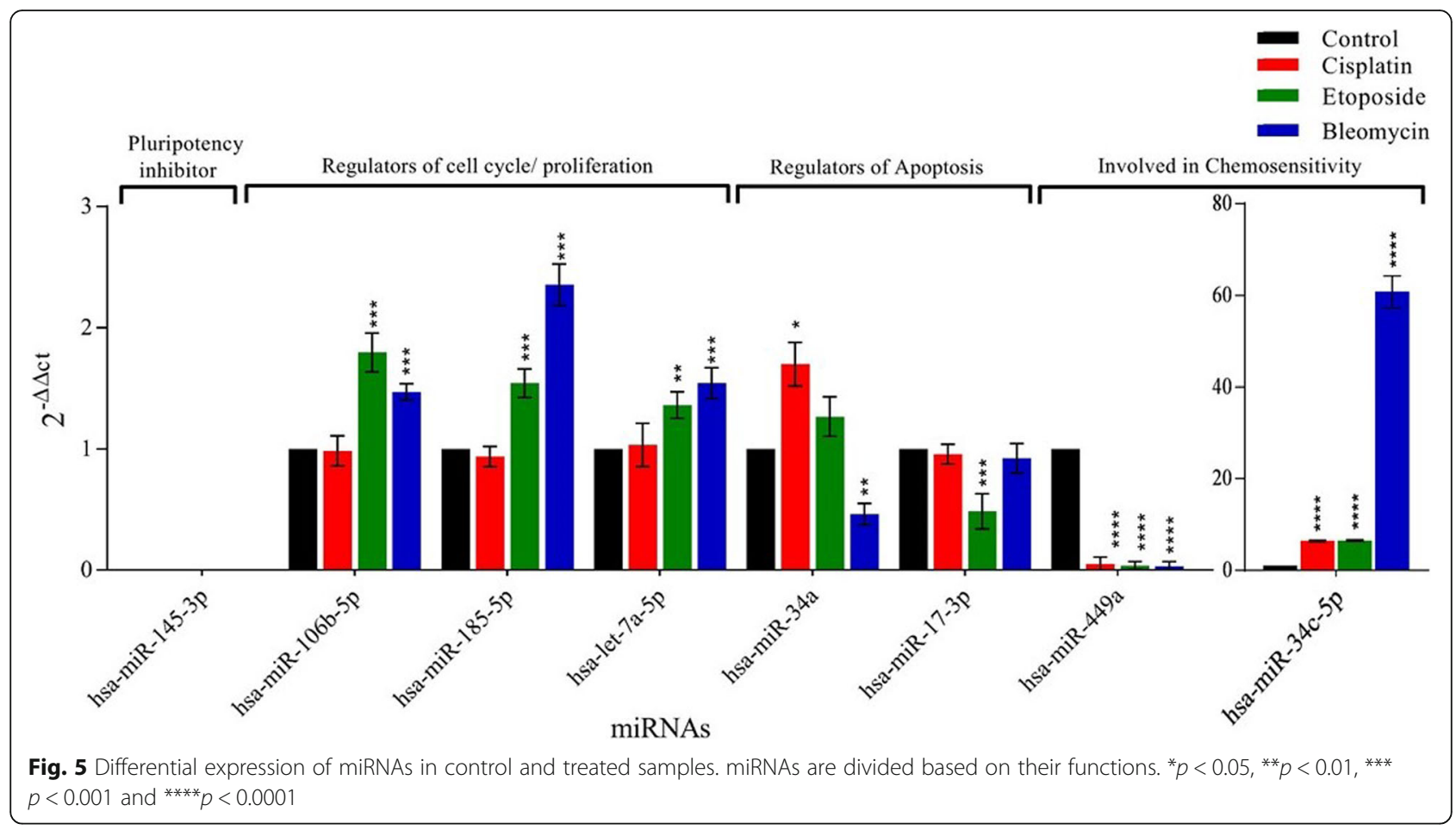

Table 6 Fold change in expression of miRNAs after treatments with cisplatin, etoposide and bleomycin with respect to control. In column 3, ' $\uparrow$ ' represents significant $(P<0.05)$ increase; ' $\downarrow$ ' represents significant $(P<0.05)$ decrease; and '-' represents non-significant $(\mathrm{P}>0.05)$ change

\begin{tabular}{|c|c|c|c|c|c|c|}
\hline \multirow{2}{*}{$\begin{array}{l}1 . \\
\text { BiologicalFunction }\end{array}$} & \multirow[t]{2}{*}{ 2. miRNA } & \multicolumn{3}{|c|}{ 3. Significant Fold change $(p<0.5)$} & \multirow[t]{2}{*}{ 4. Reports from previous studies } & \multirow[t]{2}{*}{ 5. Ref. } \\
\hline & & Cisplatin & Etoposide & Bleomycin & & \\
\hline \multirow[t]{3}{*}{ Pluripotency } & miR-145-3p & No expression & No expression & No expression & $\begin{array}{l}\text { Represses OCT4, SOX2, and KLF4 and } \\
\text { thus pluripotency in human } \\
\text { embryonic stem cells }\end{array}$ & {$[34]$} \\
\hline & miR-106b-5p & - & $1.8 \uparrow$ & $1.5 \uparrow$ & $\begin{array}{l}\text { Promotes Proliferation by targeting B3G, } \\
\text { promotes stem-cell-like phenotype }\end{array}$ & {$[35,36]$} \\
\hline & miR-185-5p & - & $1.5 \uparrow$ & $2.4 \uparrow$ & $\begin{array}{l}\text { Inhibits cell proliferation and induces } \\
\text { cell apoptosis by targeting VEGFA }\end{array}$ & {$[37]$} \\
\hline \multirow[t]{2}{*}{$\begin{array}{l}\text { Cell cycle and } \\
\text { proliferation }\end{array}$} & let-7a-5p & - & $1.4 \uparrow$ & $1.5 \uparrow$ & $\begin{array}{l}\text { High expression inhibit proliferation } \\
\text { and induce apoptosis }\end{array}$ & {$[38]$} \\
\hline & $\operatorname{miR}-34 a$ & $1.7 \uparrow$ & - & $2.1 \downarrow$ & $\begin{array}{l}\text { Ectopic miR-34a induced apoptosis } \\
\text { and a cell cycle arrest in the G1-phase, } \\
\text { by targeting p53 }\end{array}$ & {$[39,40]$} \\
\hline \multirow[t]{2}{*}{ Apoptosis } & miR-17-3p & - & $2.1 \downarrow$ & - & $\begin{array}{l}\text { miR-17-3p is downregulated when } \\
\text { p53 is active, thus inducing apotosis } \\
\text { and vice versa }\end{array}$ & {$[40]$} \\
\hline & $\operatorname{miR}-34 c-5 p$ & $6.5 \uparrow$ & $6.5 \uparrow$ & $60.8 \uparrow$ & $\begin{array}{l}\text { miR-34c-5p was downregulated in } \\
\text { paclitaxel-resistant gastric cancer samples, } \\
\text { MiR-34c enhances chemosensitivity of } \\
\text { Ishikawa cell to cisplatin }\end{array}$ & {$[41,42]$} \\
\hline Chemosensitivity & miR-449a & $19.7 \downarrow$ & $27.3 \downarrow$ & $31.6 \downarrow$ & $\begin{array}{l}\text { Ectopic expression of miR-449a increased } \\
\text { the apoptosis induced by cisplatin, miR- } 449 \text { a } \\
\text { is proapoptotic and targets BCL2 expression }\end{array}$ & {$[43,44]$} \\
\hline
\end{tabular}

The numbers in the column 3 represents 'times the fold change' after each treatment with respect to control. miRNAs are divided based on their functions. Column 4 describes their function 
expression and their roles are reported in the Table 6 . The null expression of hsa-miR-145-3p in all treated samples and controls confirms the previous finding that hsa-miR-145 represses core pluripotency factors Oct4, SOX2 and KLF4 [34]. The expression of pluripotency markers in hAFSCs and absence of hsa-miR-145 suggest that the same miRNA regulates the pluripotency in hAFSCs. Also, though all the three drugs are cytotoxic, their treatment may induce opposite and dynamic expression levels for some miRNAs, like in the case of hsamir-34a. Moreover, Bleomycin and etoposide induce the change in expression of most of the tested miRNAs, cisplatin being the least (Fig. 5). hsa-miR-34c-5p and hsamiR-449a were found to be up and down-regulated $(P<$ $0.05)$, respectively in BEP treatment with respect to control samples. Notably, bleomycin and etoposide treated cells showed high expression of hsa-miR-106b-5p, hsamiR-185- 5p and hsa-let-7a-5p, implicated in cell cycle and proliferation $(\mathrm{P}<0.05$, fold-change increase range: 1.36-2.35). The miRNAs involved in the regulation of apoptosis (hsa-miR-17-3p and miR-34a) showed variable expression in all the three treatments. In fact, miR-34a was upregulated in cisplatin and downregulated in bleomycin while hsa-miR-17-3p was downregulated only in etoposide treatment.

\section{Discussion}

Through our experiments, we have evaluated the cytotoxicity of bleomycin, etoposide and cisplatin in hAFSCs, which showed time and dose-dependent cytotoxic effect. Epigenetically, differences in the global DNA methylation, hyper as well as hypomethylation, are observed in treated cells. We revealed a significant decrease in the 5$\mathrm{mC}$ percentage in total DNA after cisplatin exposure, while a significant increase was observed after bleomycin and etoposide exposure. This result suggests that the methylation status of the genome of hAFSCs is in continuous flux during treatment. In addition, taking into consideration of our data, the chemotherapy activity could alter the pluripotency-associated genes of stem cell pool present in the adult body. These observations suggest that anti-cancer drugs can influence self-renewal and differentiation properties of stem cells. Transcriptionally, cisplatin and etoposide mediated an inhibitory effect on the expression of core pluripotency genes, concomitant with the downregulation of germline markers, particularly meiotic stage markers. On the contrary, bleomycin-induced the activation of Oct4, NANOG and SOX2 and the most of premeiotic and all meiotic markers at the transcriptional level. However, interesting enough, the three tested markers such as Oct4, NANOG and $S O X 2$ at the protein level were not upregulated, suggesting towards the previously studied phenomena that although changes in mRNA and proteins are concordant for most genes, genes that are rapidly repressed upon a stimulus, can have uncoupled mRNA and protein levels [45]. It has been suggested that such differences in mRNA and protein expression occurs due to post-transcriptional, translational and protein degradation regulation [46]. We suspect epigenetically it may be regulated by some miRNAs by binding to mRNAs, which is the future scope of this study. Along with global DNA methylation, we have also explored the methylation percentage of the promoter regions of the pluripotencyrelated genes as potential biomarkers for chemosensitivity. The most important findings were identifying methylation patterns in SOX2, C-Kit, Oct4 and NANOG genes such as the hypermethylation of DNA in the promoter of $S O X 2$, C-Kit and NANOG in cisplatin treated hAFSCs, hypomethylation of CpG islands in SOX2, Oct4 and C-Kit markers in etoposide treatment, and highly dynamic modifications of promoter $\mathrm{CpG}$ islands in bleomycin treated hAFSCs. Intriguingly, the study showed that the complete demethylation of CpGs 3 and 7 in the promoter region of Oct4. Recently, several studies have reported that not every CpG is able to influence gene expression with its methylation status; some $\mathrm{CpGs}$ are regulatory and others are not directly responsible for gene silencing $[47,48]$. However further research should be conducted to understand the functional role of each single CpG. In addition, we observed the evident no correlation between DNA methylation and gene expression in some treatments for some genes (e.g. SOX2 in bleomycin treatment). This may occur when the gene expression controlling region does not fall under our tested CpG region of the promoter, but located elsewhere in the promoter, or in some other areas of the gene, or at a distal regions of the genome that influence genome activity- for example, as promoters of non-coding RNAs [49, 50]. Another epigenetic aspect of crucial importance is represented by aberrant DNA methylation of imprinted gene H19 during chemotherapy. Our data show that imprinting alterations can occur in hAFSCs during BEP treatment. The methylation status of the paternally imprinted gene fluctuated from 54.3 to $89 \%$ during treatments with the three drugs. H19 hypomethylation was found in cells cultured with cisplatin while hypermethylation was exhibited by hAFSCs treated with etoposide and bleomycin. Considering the miRNA, we found significant differential expression of the majority of miRNAs with and without treatment. An interesting finding was the absence of expression of hsamiR-145-3p in all controls and treated hAFSCs. The null expression of hsa-miR-145-3p in all treated samples and controls confirms the previous finding that has-miR145 represses core pluripotency factors Oct4, SOX2 and KLF4 [34]. Moreover, based on our analysis, we postulated 
that two different mechanisms are responsible for the differential expression of miRNAs:

1. Due to the direct actions of chemotherapeutic agents on the cells

2. To maintain the homeostasis: (A) as defence mechanisms of the cells against the drugs and (B) to revert the changes taken at first place as direct actions of the drug(s).

We suggested that the differential change in the expression of miR-185-5p, let-7a-5p, miR-17-3p and miR$34 c-5 p$ are due to the direct action of the drugs, and their differential expression in some or all treatment are responsible for hampered proliferation [37, 38], higher chemosensitivity [41, 42] and/or apoptosis [40] of the hAFSCs. On the other hand, hsa-miR-106b-5p and miR$449 \mathrm{a}$ are responsible for the cellular defence against the drugs by promoting cellular proliferation $[35,36]$ and chemoresistance $[43,44]$, respectively. The dynamic expression of hsa- mir-34a suggest both the mechanisms. Upregulation of this miRNA in cisplatin treatment suggests hsa-miR-34a induced apoptosis and a cell cycle arrest in the G1-phase, by targeting p53, whereas downregulation in bleomycin treatment suggests the opposite phenomenon $[39,40]$. It is tempting to assume that the higher expression of pluripotency and PGC markers as we found in real-time qPCR analysis is probably due to the action of has-miR34a, but it is yet inconclusive and needs further confirmations. Therefore, the success of any chemotherapeutic treatment may depend upon the proper balance between the two above mentioned phenomenon, and understanding both of these mechanisms are crucial in designing drugs with high efficacy and minimum negative effects.

\section{Conclusion}

To our knowledge, this is the first study on genetic and epigenetic alterations carried out individually by bleomycin, cisplatin and etoposide on hAFSCs. Our study adds new findings to the present literature about the modes of action of these three chemotherapeutic agents. It is well known that these three drugs primarily target and damage cellular DNA, thus inducing apoptosis [1317]. Taken together, it was observed that each drug could kill stem cells, significantly alter their stemness and other cell properties and bring various epigenetic changes, and this might cause the various negative effects after chemotherapy. Regarding the negative or side effects of the drugs, the decrease in stem cell pool and these epigenetic changes combined, due to chemotherapy can be the contributing factors for alopecia [51], infertility [52] and neurological impairments [53].

Though our in-vitro study is performed on a stem cell lineage, it is not erroneous to assume that chemotherapy may induce epigenetic changes to all the cell of the body to some extent. Literature suggest that the epigenetic makeup of non-stem cells gets affected as well due to the actions of cisplatin [54], etoposide [55, 56] and bleomycin [57]. Moreover, introducing other drugs and other types of body cells in such studies might help us to get more insights into epigenetic changes due to chemotherapy. This could provide us with a better understanding of cancer, its suitable treatment and management of the side effects. In addition, further investigations are still needed to clarify the epigenetic effect of the BEP regimen in different stem and non stem cell types. In summary, the results considered more important for the toxicity of the drugs are related with alterations of epigenetic machinery, and each anticancer agents showed a different effect in terms of stemness, cell growth and proliferation. Conclusively, this study evokes us to consider that other widely used chemotherapeutic drugs may have the potential to change epigenetic makeup throughout the stem cell pools of the body. However, it is important to improve our understanding of the molecular modifications underlying complex cellular mechanisms and try to consider each drug target in its full epigenetic context $[58,59]$.

\section{Supplementary information}

Supplementary information accompanies this paper at https://doi.org/10. 1186/s12920-019-0595-3.

Additional file 1: SI1. Drugs preparation. SI2. The 5-mC\% values of controls and for each treatment.

\section{Abbreviations}

$\triangle \triangle \mathrm{Ct}$ : delta delta Ct; 5-mC: 5'-methylcytosine; ANOVA: Analysis of Variance; BEP: Bleomycin, Etoposide and Cisplatin; Ct: Threshold cycle; hAFSCs: Human Amniotic Fluid Stem Cells; IMDM: Iscove's Modified Dulbecco's Medium; MFI: Mean Fluorescence Intensity; miRNA: micro-RNA; MTT: 3-(4,5dimethylthiazol-2-yl)-2,5-diphenyl tetrazolium bromide; PBS: Phosphate Buffered Saline

\section{Acknowledgements}

We thank Daniela Di Tizio for her technical assistance.

\section{Authors' contributions}

PU performed all the experiments, assembled, analysed and interpreted the data and wrote the manuscript. ADS, LS and PB analyzed the data and helped in study design. MM and LP coordinated and performed the flow cytometry experiments. LS and IA conceived and designed the study, analyzed and interpreted the data. All authors read and approved the final manuscript.

\section{Funding}

This study was supported by grants from the Italian Ministry of University and Research (MIUR) 2015 prot. 20157FF4KM_002 to Liborio Stuppia. The funding body played no role in the design of the study and collection, analysis, and interpretation of data and in writing the manuscript.

\section{Availability of data and materials}

The sequence information about the miRNAs used in the study can be found by entering the stem loop accession number (provided in the Table 3) at miRBase (Release 22.1) repository, [http://www.mirbase.org/]. 
The procedure of drugs preparation can be found on supplementary information SI1. The global DNA methylation percentages across different lines of hAFSCs in control and treatments and are made available as supplementary information SI2.

\section{Ethics approval and consent to participate}

The amniotic fluid samples used in this study were collected from the women undergoing amniocentesis for prenatal diagnosis at 16-18 weeks of pregnancy after obtaining written informed consent. The experimental protocol was approved by the Ethics Committee of the University of ChietiPescara, Italy.

\section{Consent for publication}

Not applicable.

\section{Competing interests}

The authors declare they have no competing interests.

Received: 25 May 2019 Accepted: 26 September 2019

Published online: 28 October 2019

\section{References}

1. Jemal A, Bray F, Center MM, Ferlay J, Ward E, Forman D. Global cancer statistics. CA Cancer J Clin. 2011;61:69-90. https://doi.org/10.3322/caac. 20107.

2. Gandikota N, Hartridge-Lambert S, Migliacci JC, Yahalom J, Portlock CS, Schöder H. Very low utility of surveillance imaging in early-stage classic Hodgkin lymphoma treated with a combination of doxorubicin, bleomycin, vinblastine, and dacarbazine and radiation therapy. Cancer. 2015;121:198592. https://doi.org/10.1002/cncr.29277.

3. Jafri SH, Glass J, Shi R, Zhang S, Prince M, Kleiner-Hancock H. Thymoquinone and cisplatin as a therapeutic combination in lung cancer: in vitro and in vivo. J Exp Clin Cancer Res. 2010;29:87. https://doi.org/10.1186/1756-996629-87.

4. Commander LA, Seif AE, Insogna IG, Rheingold SR. Salvage therapy with nelarabine, etoposide, and cyclophosphamide in relapsed/refractory paediatric T-cell lymphoblastic leukaemia and lymphoma. Br J Haematol. 2010;150:345-51. https://doi.org/10.1111/j.1365-2141.2010.08236.x.

5. Linnert M, Gehl J. Bleomycin treatment of brain tumors: an evaluation. AntiCancer Drugs. 2009;20:157-64. https://doi.org/10.1097/CAD. ob013e328325465e.

6. Cadron I, Van Gorp T, Amant F, Leunen K, Neven P, Vergote I. Chemotherapy for recurrent cervical cancer. Gynecol Oncol. 2007;107:S1138. https://doi.org/10.1016/J.YGYNO.2007.07.004

7. Chen G, Huynh M, Fehrenbacher L, West H, Lara PN, Yavorkovsky LL, et al. Phase II trial of irinotecan and carboplatin for extensive or relapsed smallcell lung cancer. J Clin Oncol. 2009:27:1401-4. https://doi.org/10.1200/JCO. 2008.20.2127.

8. Koizumi W, Narahara H, Hara T, Takagane A, Akiya T, Takagi M, et al. S-1 plus cisplatin versus S-1 alone for first-line treatment of advanced gastric cancer (SPIRITS trial): a phase III trial. Lancet Oncol. 2008;9:215-21. https://doi.org/ 10.1016/S1470-2045(08)70035-4

9. Ajani JA, Winter KA, Gunderson LL, Pedersen J, Benson AB, Thomas CR, et al. Fluorouracil, Mitomycin, and radiotherapy vs fluorouracil, Cisplatin, and radiotherapy for carcinoma of the Anal Canal. JAMA. 2008;299:1914. https:// doi.org/10.1001/jama.299.16.1914

10. Feldman DR, Bosl GJ, Sheinfeld J, Motzer RJ. Medical treatment of advanced testicular Cancer. JAMA. 2008;299:672. https://doi.org/10.1001/jama.299.6. 672 .

11. de Wit R, Skoneczna I, Daugaard G, De Santis M, Garin A, Aass N, et al. Randomized phase III study comparing paclitaxel-Bleomycin, Etoposide, and Cisplatin (BEP) to standard BEP in intermediate-prognosis germ-cell Cancer: intergroup study EORTC 30983. J Clin Oncol. 2012;30:792-9. https:// doi.org/10.1200/JCO.2011.37.0171

12. Low JJH, llancheran A, Ng JS. Malignant ovarian germ-cell tumours. Best Pract Res Clin Obstet Gynaecol. 2012;26:347-55. https://doi.org/10.1016/J. BPOBGYN.2012.01.002

13. Dasari S, Bernard TP. Cisplatin in cancer therapy: molecular mechanisms of action. Eur J Pharmacol. 2014:740:364-78. https://doi.org/10.1016/J.EJPHAR. 2014.07.025
14. Siddik ZH. Cisplatin: mode of cytotoxic action and molecular basis of resistance. Oncogene. 2003:22:7265. https://doi.org/10.1038/sj.onc.1206933.

15. Cort A, Ozben T, Melchiorre M, Chatgilialoglu C, Ferreri C, Sansone A. Effects of bleomycin and antioxidants on the fatty acid profile of testicular cancer cell membranes. Biochim Biophys Acta Biomembr. 1858;2016:434-41. https://doi.org/10.1016/J.BBAMEM.2015.12.005

16. Montecucco A, Biamonti G. Cellular response to etoposide treatment. Cancer Lett. 2007;252:9-18. https://doi.org/10.1016/J.CANLET.2006.11.005.

17. Preusser $\mathrm{P}$, Wilke $\mathrm{H}$, Achterrath $\mathrm{W}$, Fink U, Lenaz L, Heinicke A, et al. Phase II study with the combination etoposide, doxorubicin, and cisplatin in advanced measurable gastric cancer. https://doi.org/101200/JCO198979131 0. 2016;7:1310-7. https://doi.org/10.1200/JCO.1989.7.9.1310.

18. Ren J, Singh BN, Huang Q, Li Z, Gao Y, Mishra P, et al. DNA hypermethylation as a chemotherapy target. Cell Signal. 2011;23:1082-93. https://doi.org/10.1016/J.CELLSIG.2011.02.003.

19. El-Awady RA, Hersi F, Al-Tunaiji H, Saleh EM, Abdel-Wahab A-HA, Al Homssi $A$, et al. Epigenetics and miRNA as predictive markers and targets for lung cancer chemotherapy. Cancer Biol Ther. 2015;16:1056-70. https://doi.org/10. 1080/15384047.2015.1046023.

20. Baker EK, El-Osta A. MDR1 , Chemotherapy and chromatin remodeling. Cancer Biol Ther. 2004;3:819-24. https://doi.org/10.4161/cbt.3.9.1101.

21. Natanzon Y, Goode EL, Cunningham JM. Epigenetics in ovarian cancer. Semin Cancer Biol. 2018;51:160-9. https://doi.org/10.1016/J.SEMCANCER. 2017.08.003.

22. Chan D, Delbès $G$, Landry $M$, Robaire $B$, Trasler JM. Epigenetic alterations in sperm DNA associated with testicular cancer treatment. Toxicol Sci. 2012; 125:532-43. https://doi.org/10.1093/toxsci/kfr307.

23. Stuppia L, Franzago M, Ballerini P, Gatta V, Antonucci I. Epigenetics and male reproduction: the consequences of paternal lifestyle on fertility, embryo development, and children lifetime health. Clin Epigenetics. 2015;7: 120. https://doi.org/10.1186/s13148-015-0155-4.

24. Rühle A, Huber PE, Saffrich R, Lopez Perez R, Nicolay NH. The current understanding of mesenchymal stem cells as potential attenuators of chemotherapy-induced toxicity. Int J Cancer. 2018;143:2628-39. https://doi. org/10.1002/ijc.31619.

25. Liu S, Yin N, Faiola F. Prospects and Frontiers of stem cell toxicology. Stem Cells Dev. 2017;26:1528-39. https://doi.org/10.1089/scd.2017.0150.

26. De Coppi P, Bartsch G, Siddiqui MM, Xu T, Santos CC, Perin L, et al. Isolation of amniotic stem cell lines with potential for therapy. Nat Biotechnol. 2007; 25:100-6. https://doi.org/10.1038/nbt1274.

27. Antonucci I, Pantalone A, Tete S, Salini V, Borlongan CV, Hess D, et al. Amniotic fluid stem cells: a promising therapeutic resource for cell-based regenerative therapy. Curr Pharm Des. 2012;18:1846-63. https://doi.org/10. 2174/138161212799859602.

28. Antonucci I, Di Pietro R, Alfonsi M, Centurione MA, Centurione L, Sancilio S, et al. Human second trimester amniotic fluid cells are able to create embryoid body-like structures in vitro and to show typical expression profiles of embryonic and primordial germ cells. Cell Transplant. 2014;23: $1501-15$.

29. Pipino C, Pandolfi A. Osteogenic differentiation of amniotic fluid mesenchymal stromal cells and their bone regeneration potential. World Stem Cells. 2015;7:681. https://doi.org/10.4252/wjsc.v7.i4.681.

30. Di Tizio D, Di Serafino A, Upadhyaya P, Sorino L, Stuppia L, Antonucci I \%J S cells international. The Impact of Epigenetic Signatures on Amniotic Fluid Stem Cell Fate. Stem Cells Int. 2018:2018.

31. Antonucci I, Provenzano M, Rodrigues M, Pantalone A, Salini V, Ballerini P, et al. Amniotic fluid stem cells: a novel source for modeling of human genetic diseases. Int J Mol Sci. 2016;17.

32. D'Alimonte I, Lannutti A, Pipino C, Di Tomo P, Pierdomenico L, Cianci E, et al. Wnt signaling behaves as a \&quot;master regulator\&quot; in the osteogenic and adipogenic commitment of human amniotic fluid mesenchymal stem cells. Stem Cell Rev. 2013;9:642-54. https://doi.org/10. 1007/s12015-013-9436-5.

33. Pipino C, Di Tomo P, Mandatori D, Cianci E, Lanuti $P$, Cutrona MB, et al. Calcium sensing receptor activation by Calcimimetic R-568 in human amniotic fluid Mesenchymal stem cells: correlation with Osteogenic differentiation. Stem Cells Dev. 2014;23:2959-71. https://doi.org/10.1089/scd. 2013.0627.

34. Xu N, Papagiannakopoulos T, Pan G, Thomson JA, Kosik KS. MicroRNA-145 regulates OCT4, SOX2, and KLF4 and represses pluripotency in human embryonic stem cells. Cell. 2009;137:647-58. 
35. Wei K, Pan C, Yao G, Liu B, Ma T, Xia Y, et al. MiR-106b-5p promotes proliferation and inhibits apoptosis by regulating BTG3 in non-small cell lung Cancer. Cell Physiol Biochem. 2017:44:1545-58. https://doi.org/10.1159/ 000485650.

36. Lu J, Wei J-H, Feng Z-H, Chen Z-H, Wang Y-Q, Huang Y, et al. miR-106b-5p promotes renal cell carcinoma aggressiveness and stem-cell-like phenotype by activating Wnt/ß-catenin signalling. Oncotarget. 2017;8:21461-71. https:// doi.org/10.18632/oncotarget.15591.

37. Ma X, Shen D, Li H, Zhang Y, Lv X, Huang Q, et al. MicroRNA-185 inhibits cell proliferation and induces cell apoptosis by targeting VEGFA directly in von Hippel-Lindau-inactivated clear cell renal cell carcinoma. Urol Oncol Semin Orig Investig. 2015;33:169.e1-169.e11. https://doi.org/10.1016/J. UROLONC.2015.01.003

38. Deng H-X, Yu Y-Y, Zhou A-Q, Zhu J-L, Luo L-N, Chen W-Q, et al. Yangzheng Sanjie decoction regulates proliferation and apoptosis of gastric cancer cells by enhancing let-7a expression. World J Gastroenterol. 2017;23:5538-48. https://doi.org/10.3748/wjg.v23.i30.5538.

39. Hermeking $H$. The miR-34 family in cancer and apoptosis. Cell Death Differ. 2010;17:193-9. https://doi.org/10.1038/cdd.2009.56.

40. Tarasov V, Jung P, Verdoodt B, Lodygin D, Epanchintsev A, Menssen A, et al. Differential regulation of microRNAs by $\mathrm{p} 53$ revealed by massively paralle sequencing: miR-34a is a p53 target that induces apoptosis and G 1-arrest. Cell Cycle. 2007;6:1586-93. https://doi.org/10.4161/cc.6.13.4436.

41. Jiang L, Meng W, Zeng J, Hu H, Lu L. MiR-34c oligonucleotide enhances chemosensitivity of Ishikawa cell to cisplatin by inducing apoptosis. Cell Biol Int. 2013;37:577-83. https://doi.org/10.1002/cbin.10074

42. Wu H, Huang M, Lu M, Zhu W, Shu Y, Cao P, et al. Regulation of microtubule-associated protein tau (MAPT) by miR-34c-5p determines the chemosensitivity of gastric cancer to paclitaxel. Cancer Chemother Pharmacol. 2013;71:1159-71. https://doi.org/10.1007/s00280-013-2108-y.

43. Hu J, Fang Y, Cao Y, Qin R, Chen Q. miR-449a regulates proliferation and chemosensitivity to cisplatin by targeting cyclin D1 and BCL2 in SGC7901 cells. Dig Dis Sci. 2014;59:336-45.

44. Chen J, Zhou J, Chen X, Yang B, Wang D, Yang P, et al. miRNA-449a is downregulated in osteosarcoma and promotes cell apoptosis by targeting BCL2. Tumor Biol. 2015;36:8221-9. https://doi.org/10.1007/s13277-015-3568-y.

45. Torres-Padilla M-E, Chambers I. Transcription factor heterogeneity in pluripotent stem cells: a stochastic advantage. Development. 2014;141: 2173-81. https://doi.org/10.1242/dev.102624.

46. Vogel C, Marcotte EM. Insights into the regulation of protein abundance from proteomic and transcriptomic analyses. Nat Rev Genet. 2012;13:22732. https://doi.org/10.1038/nrg3185

47. Miao Z, Wu L, Lu M, Meng X, Gao B, Qiao X, et al. Analysis of the transcriptional regulation of cancer-related genes by aberrant DNA methylation of the cis-regulation sites in the promoter region during hepatocyte carcinogenesis caused by arsenic. Oncotarget. 2015;6:21493506. https://doi.org/10.18632/oncotarget.4085.

48. Eckstein M, Rea M, Fondufe-Mittendorf YN. Transient and permanent changes in DNA methylation patterns in inorganic arsenic-mediated epithelial-to-mesenchymal transition. Toxicol Appl Pharmacol. 2017;331:617. https://doi.org/10.1016/j.taap.2017.03.017.

49. Zhang X, Ulm A, Somineni HK, Oh S, Weirauch MT, Zhang H-X, et al. DNA methylation dynamics during ex vivo differentiation and maturation of human dendritic cells. Epigenetics Chromatin. 2014;7:21. https://doi.org/10. 1186/1756-8935-7-21.

50. Suzuki MM, Bird A. DNA methylation landscapes: provocative insights from epigenomics. Nat Rev Genet. 2008;9:465-76. https://doi.org/10.1038/ nrg2341.

51. Hesketh P, Batchelor D, Golant M, Lyman G, Rhodes N, Yardley D. Chemotherapy-induced alopecia: psychosocial impact and therapeutic approaches. Support Care Cancer. 2004;12:543-9. https://doi.org/10.1007/ s00520-003-0562-5.

52. Dohle GR. Male infertility in cancer patients: review of the literature. Int Urol. 2010;17:327-31. https://doi.org/10.1111/j.1442-2042.2010.02484.x

53. Kannarkat G, Lasher EE, Schiff D. Neurologic complications of chemotherapy agents. Curr Opin Intern Med. 2008;7:88-94. https://doi.org/10.1097/WCO. ob013e3282f1a06e

54. Shen D-W, Pouliot LM, Hall MD, Gottesman MM. Cisplatin resistance: a cellular self-defense mechanism resulting from multiple epigenetic and genetic changes. Pharmacol Rev. 2012;64:706-21. https://doi.org/10.1124/PR. 111.005637
55. Dere E, Anderson LM, Hwang K, Boekelheide K. Biomarkers of chemotherapy-induced testicular damage. Fertil Steril. 2013;100:1192-202. https://doi.org/10.1016/j.fertnstert.2013.09.017.

56. Ji Z, Zhang L, Peng V, Ren X, McHale CM, Smith MT. A comparison of the cytogenetic alterations and global DNA hypomethylation induced by the benzene metabolite, hydroquinone, with those induced by melphalan and etoposide. Leukemia. 2010;24:986-91. https://doi.org/10.1038/leu.2010.43.

57. Yang IV, Schwartz DA. Epigenetics of idiopathic pulmonary fibrosis. Transl Res. 2015;165:48-60. https://doi.org/10.1016/J.TRSL.2014.03.011.

58. The role of pharmacogenomics in adverse drug reactions. Cacabelos R1, Cacabelos N1, Carril JC1.Expert Rev Clin Pharmacol. 2019 May;12(5):407-442. doi: https://doi.org/10.1080/17512433.2019.1597706. Epub 2019 Apr 24.

59. Epigenetic side-effects of common pharmaceuticals: a potential new field in medicine and pharmacology. Csoka AB1, Szyf M. Med Hypotheses. 2009 Nov;73(5):770-80. doi: https://doi.org/10.1016/j.mehy.2008.10.039. Epub 2009 Jun 5 .

\section{Publisher's Note}

Springer Nature remains neutral with regard to jurisdictional claims in published maps and institutional affiliations.

\section{Ready to submit your research? Choose BMC and benefit from:}

- fast, convenient online submission

- thorough peer review by experienced researchers in your field

- rapid publication on acceptance

- support for research data, including large and complex data types

- gold Open Access which fosters wider collaboration and increased citations

- maximum visibility for your research: over $100 \mathrm{M}$ website views per year

At $\mathrm{BMC}$, research is always in progress.

Learn more biomedcentral.com/submissions 